\title{
Fitball as an effective means of strengthening the physical health of preschool children
}

Fitball como medio eficaz para fortalecer la salud física de los niños en edad preescolar

\author{
Natalya Mischenko \\ Ural State University of Physical Culture, Department of \\ Theory and Methods of Physical Education, Rusia \\ numishenko@yandex.ru
}

https://orcid.org/0000-0001-8405-5348

\author{
Elena Romanova \\ Altai State University, Department of Physical Education, \\ Rusia \\ romanovaev.2007@mail.ru
}

(D) https://orcid.org/0000-0003-4317-605X

\author{
Mikbail Kolokoltsev \\ Irkutsk National Research Technical University, \\ Department of Physical Culture, Rusia \\ mihm49@mail.ru \\ (iD https://orcid.org/0000-0001-6620-6296
}

Victor Kraynik

Altai State Pedagogical University, Department of Sports

Disciplines, Institute of Physical Culture and Sports, Rusia

kraynikviktor@mail.ru

(iD https://orcid.org/ 0000-0002-2090-1303

\author{
Svetlana Kubiyeva \\ Aktobe Regional University named after K. Zhubanov, \\ Department of Physical Culture and Sport, Kazajistán \\ Kubieva_S@mail.ru \\ iD https://orcid.org/0000-0002-7237-922X
}

\begin{abstract}
:
The article outlines the problem of pre-school children's health preserving and strengthening. One of the ways to solve the problems of improving children's health and preventing various diseases is proposed - fitball aerobics classes, as a type of fitness aerobics using large gymnastic balls - fitballs. The objective of this research is to characterize fitball-aerobics, as preschool children's innovative means of physical education and to develop a methodology for the complex effects of fitball-aerobics exercises on the development of physical abilities of preschool children's age in order to determine its effectiveness. The research was conducted in the period from 2016 to 2018 in educational organizations of preschool education in Chelyabinsk. Children of preschool age took part in the aged 5-7 years. A total of 40 children participated in the experiment, 20 people in the control group and other 20, in experimental one. The work done does not infringe on the rights and does not jeopardize the well-being of schoolchildren in accordance with the ethical standards of the Committee for the Rights of Experiments of the Helsinki Declaration. Parental consent to examine children was obtained. The developed and tested methodology for the complex effect of fitball-aerobics exercises on preschool children's physical abilities development had a possitive impact.
\end{abstract}

KeYwords: Fitball balls, Fitball aerobics, Physical Education, Physical abilities, Children of Preschool Age. 


\section{RESUMEN:}

El artículo describe el problema de la preservación y el fortalecimiento de la salud de los niños en edad preescolar. Propone las clases de aeróbica-fitball, un tipo de fitness aeróbico que utiliza pelotas de gimnasia grandes, las fitballs como una de las formas de resolver los problemas para mejorar la salud de los niños y prevenir diversas enfermedades. Los objetivos de la investigación son caracterizar el fitball-aeróbic como medio innovador de educación física para niños en edad preescolar, desarrollar una metodología para los efectos complejos de los ejercicios aeróbicos-fitball en el desarrollo de las habilidades físicas de los niños en edad preescolar, para determinar su efectividad. La investigación se llevó a cabo en el período de 2016 a 2018 en organizaciones educativas de educación preescolar en Chelyabinsk. Los niños en edad preescolar que participaron tenían entre 5 y 7 años. Un total de 40 niños participaron en el experimento, 20 personas en el grupo de control y 20 en el experimental. El trabajo realizado no viola los derechos y no pone en peligro el bienestar de los escolares de acuerdo con las normas éticas del Comité de Derechos de Experimentación de la Declaración de Helsinki. Se obtuvo el consentimiento de los padres para examinar a los niños. La metodología desarrollada y probada para el efecto complejo de los ejercicios aeróbicos-fitball en el desarrollo de las habilidades físicas de los niños en edad preescolar tuvo un impacto positivo.

Palabras Clave: Balones de Fitball, Aeróbicos de Fitball, Educación Física, Habilidades físicas, Niños en Edad Preescolar.

\section{INTRODUCTION}

Preschool age children protection and promotion health, improving child's body functions and its full physical development are an integral part of pedagogical work in educational organizations of preschool education (EOPE). Meanwhile, in preschool age, already a significant part of children (68\%) experience multiple functional disorders, $17 \%$ of children acquire chronic diseases, and only one out of three children remains healthy (Kuchma, 2006; Stepanova, 2006). Preschooler's health indicators analysis over the past decade has revealed unfavorable trends: the first group of health, including healthy children with normal physical and mental development, without anatomical defects, functional and morphofunctional abnormalities, decreased by 2.7 times (from 15.6 to 5.7\%), while the number of the 3rd health group, which consisting of children with chronic diseases, with physical disabilities, with an intellectual disability (http: //www.efsupit.ro/images/stories/iunie2018/Art\%20125.pdf) (Protic \& Válková, 2018). the consequences of injuries and operations (from 11.8 to 26.9\%), increased by 2,3 times. Most children (60-70\%) in all age groups have 3-4 morphofunctional deviations, only 10-20\% of children have 1-2 deviations (Lobanov et al., 2019). An alarming is increase in the number of children with five or more morphofunctional abnormalities, the leading ones being disorders of the musculoskeletal system and cardiovascular functions, digestive organs, allergic diseases (Metalnikov et al., 2020).

One of the ways to solve the problems of children's health and various diseases prevention is fitball aerobics - a type of fitness aerobics using large gymnastic balls (fitballs) (Saykina, 2008; Mishchenko, 2019; Pesina, 2019). Exercises on fitballs create a healing effect, which is confirmed by the experience of specialized correctional (Symonik et al., 2018) and rehabilitation medical centers in Europe and Russia. They make it possible to solve various problems in the complex due to the inclusion in the work of simultaneously motor, vestibular, auditory, visual, tactile and olfactory analyzers (Bedran, 2016).

Thus, they positively affect the physical and psycho-emotional state of those involved and are of great interest in children (Saykina, 2011; Veselovskaya, 1998).

The effectiveness gymnastic exercises with fitballs use in practice of preschool children's physical education and recovery is confirmed by numerous scientific studies of doctors, teachers, psychologists (Borisova, 2012; Denisenko, 2014; Zakharova, 2013; Kolesnikova, 2005). However, studies aimed at studying the complex effects of fitball-aerobics on the development of physical abilities, healing and improving the psychoemotional state of preschool children's are clearly not enough.

In this regard, the relevance of the study is caused by the following contradictions: 
- the request of society in a healthy harmoniously developed rising generation and preschool children's low level of health, physical development and physical abilities;

- the wide possibilities of fitball-aerobics classes impact on the body of those engaged in order to solve various problems and the lack of methodology development the complex effects of fitball-aerobics exercises on increasing the level of physical fitness, improving health status, and creating a steady interest in physical exercises;

- the practice of introducing fitballs into educational organizations of preschool education (EOPE) of various types and kinds, and the lack of software and methodological support for fitball-aerobics classes.

The purpose of the study is to develop and determine the effectiveness of the methodology for fitballaerobics exercises complex effects on the development of physical abilities preschool aged children's.

Object of study - preschool aged children's process of physical education.

The subject of the study is the complex effect of fitball-aerobics exercises on the development of physical abilities of children of preschool age.

Research hypothesis. The developed methodology for the complex effect of fitball-aerobics exercises on the development of physical abilities preschool children will be effective if:

- fitball-aerobics are used in all forms and types of work on the physical education of preschool children's, adequate to the age characteristics of children aged 5-7 and the actual state of those involved;

- the developed complexes of fitball-aerobics have a different orientation, plot, they are conducted under musical accompaniment;

- the properties of fitball (color, shape, size, elasticity, smell) are taken into account; the multifunctionality of its use (as a support, object, weighting device, simulator, obstacle, massager, landmark).

Research Objectives:

1. To characterize fitball-aerobics, as preschool children's innovative means of physical education.

2. To establish factors determining the complex effect of fitball-aerobics exercises on the development of physical abilities of children of preschool age.

3. Determine the fitball aerobics used in the physical education of preschool childrens.

4. To develop a methodology for the complex effects of fitball-aerobics exercises on the development of physical abilities of preschool children's age, to determine its effectiveness.

\section{Methods}

Methodology and organization of research. The research was conducted in the period from 2016 to 2018 on the basis into educational organizations of preschool education No. 366 "Korablik (Ship)" in Chelyabinsk. Children of preschool age took part in the aged 5-7 years. A total of 40 children participated in the experiment, 20 people in the control group, 20 - in experimental one. The work done does not infringe on the rights and does not jeopardize the well-being of schoolchildren in accordance with the ethical standards of the Committee for the Rights of Experiments of the 2008 Helsinki Declaration (WMA Declaration of Helsinki - Ethical Principles for Medical Research Involving Human Subjects). Parental consent to examine children was obtained.

The experimental groups were engaged in the program of physical education for preschool organizations "Raduga (Rainbow)" (Grizik et al., 2010). The classes of the experimental group included fitball- 
aerobics exercises that contribute to the development of strength, flexibility, movements coordination and equilibrium functions. Physical exercises complexes in fitball-aerobics were developed taking into account the children's age characteristics, their motor experience, the level of motor skills formation, i.e. were focused on children aged 5-7. We spent daily assess-ment of physical activity, based on the experience of foreign researchers (Kondakov et al., 2020)

\section{Results}

The results of the study were subjected to statistical processing with the calculation of the arithmetic mean value, standard deviation, arithmetic mean error, student $t$-test, error probability according to the table of this coefficient (Grjibovski, 2003). In developing the exercises complexes, we relied on the classification of exercises proposed by Ovchinnikova and Potapchuk (2009).

The complexes included exercises:

- using various initial positions of children on fitball balls;

- with a change in speed and pace of movement;

- using various methods of performing exercises;

- using coordinated movements in pairs and in a group (together, in a group, holding hands, sit down and stand up, perform turns, bends, jumps. Table 1 presents the approximate number of classes using fitball balls.

\section{TABLE 1}

The approximate number of lessons per month using fitballs, organized with preschoolers 5-7 aged. The table shows the authors' own research results.

\begin{tabular}{|c|l|c|}
\hline № & \multicolumn{1}{|c|}{ Forms of classes } & $\begin{array}{c}\text { Number of lessons } \\
\text { per month }\end{array}$ \\
\hline 1 & Morning hygienic gymnastics & 5 \\
\hline 2 & $\begin{array}{l}\text { Regular educational activity } \\
\text { physical education classes) }\end{array}$ & $2-3$ \\
\hline 3 & Corrective gymnastics & 8 \\
\hline 4 & Individual sessions & Of necessity \\
\hline 5 & Independent motor activity & Of necessity \\
\hline 6 & $\begin{array}{l}\text { Sports activities, holidays, } \\
\text { entertainment }\end{array}$ & 2 \\
\hline 7 & $\begin{array}{l}\text { Work "Fitball-aerobics" study } \\
\text { group }\end{array}$ & 2 \\
\hline
\end{tabular}

Forms of using fitball with older preschool children in the process of organizing and conducting various types of physical education work are presented in Figure 1. 
FIG.1

Forms of using fitball in the classroom with preschool aged children's. Figure 1 is author's development. The figure shows the authors' own research results.

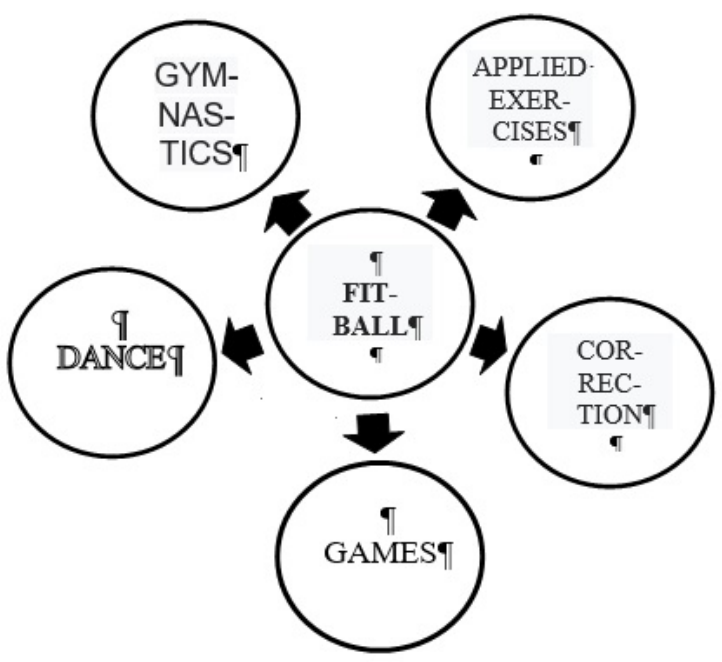

Variants for using fitballs in the preparatory part of a physical education (PE) lessons with older preschool children are presented in Figure 2.

FIG. 2

Variants for using fitballs in the preparatory physical education (PE) classes with children preschool aged. The figure shows the authors' own research results.

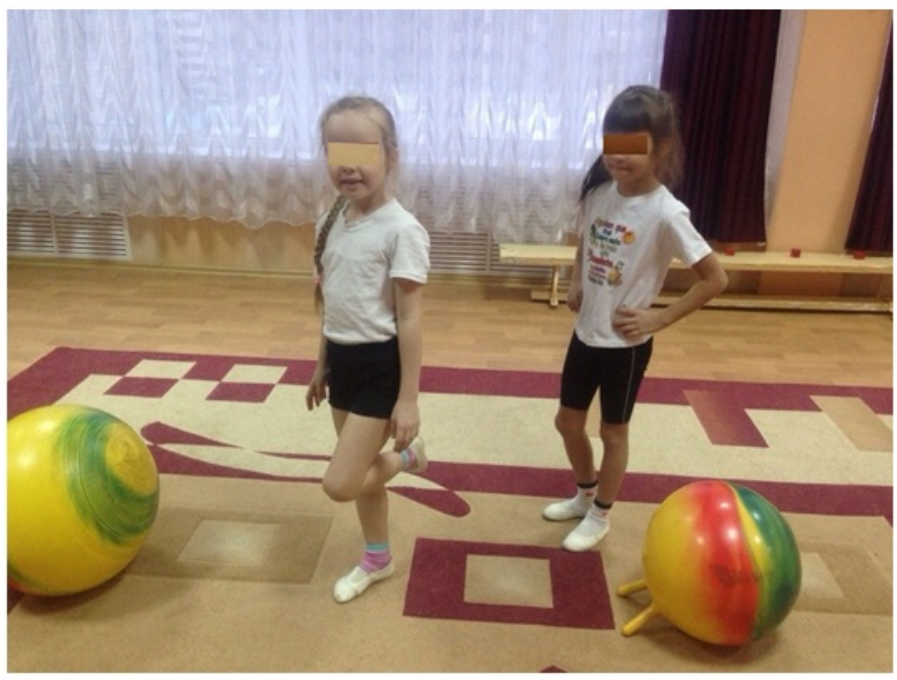

1. "Loose" walking between fitballs



2. Walking and tossing fitballs

The options for using fitballs in the main part of the physical education (PE) lesson with older preschool children are presented in Figure 3. The figure shows the authors' own research results. 
FIG. 3

Variants of using fitballs in the main part of PE classes with preschool aged children's. The figure shows the authors' own research results.

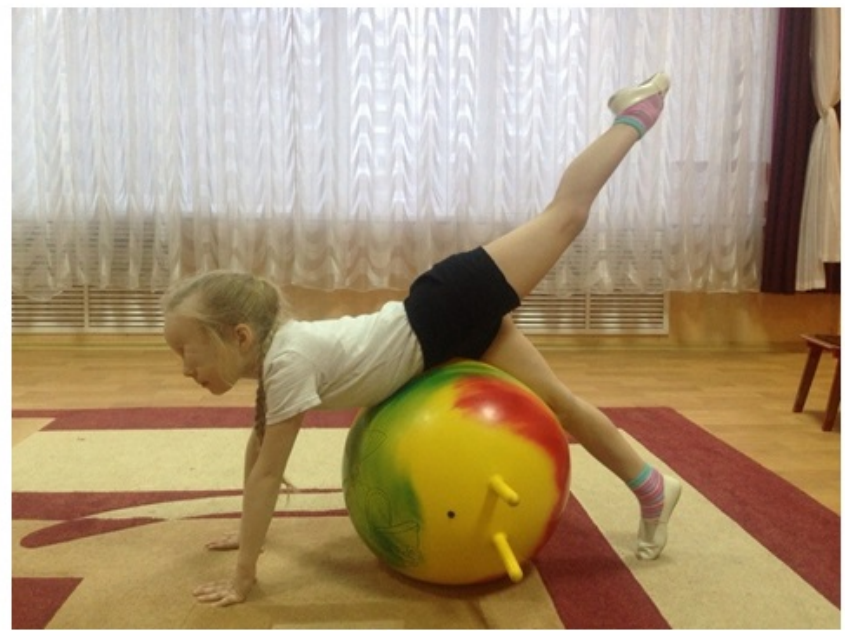

1. Lying on stomach on a fitball
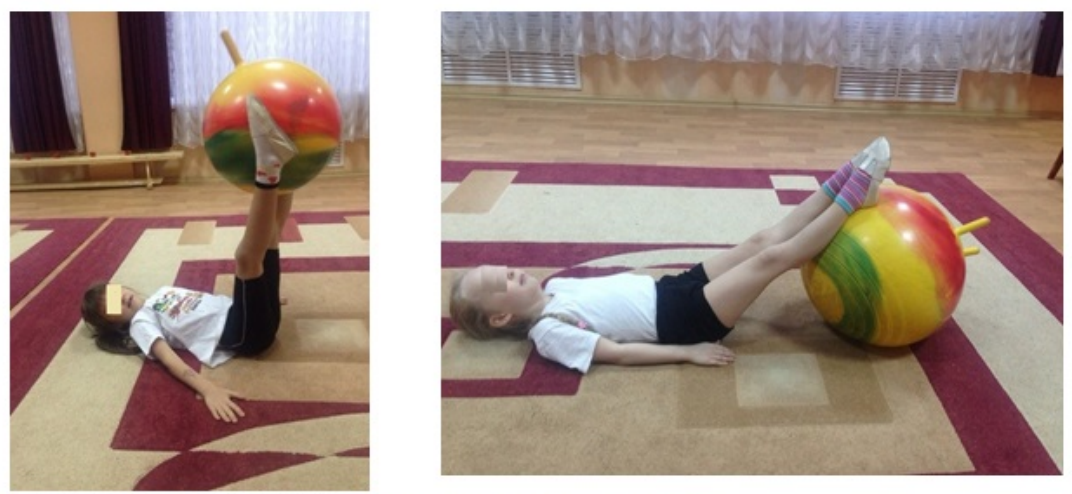

2. Lying on the back with a fitball

Variants for using fitballs in outdoor games with older preschool children are shown in Figure 4 The figure shows the authors' own research results. 
FIG. 4

Variants for using fitball in outdoor games. The figure shows the authors' own research results

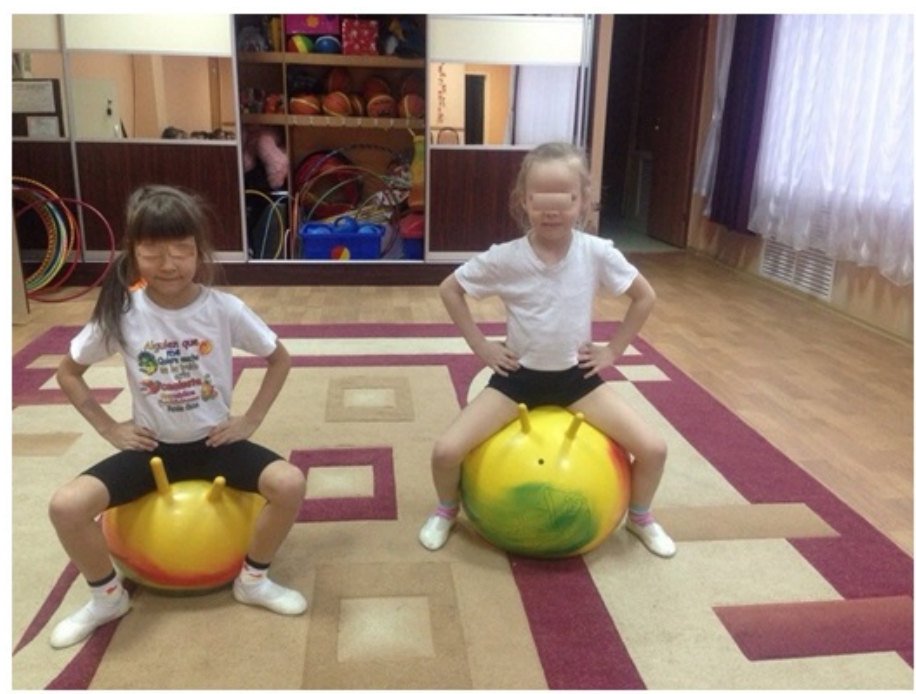

Variants for using fitball in the final part of the physical culture lesson are presented in Figure 5. The effectiveness of applying our developed methodology for the complex effects of fitball-aerobics exercises on the development of preschool children's physical abilities was evaluated on the basis of analysis and generalization of the pedagogical experiment results. An examination of the physical abilities children in the experimental groups carried out before the start of the experiment (September 2016) made it possible to draw a conclusion about the absence of significant differences between them (table $2 ; 3$ ).

FIG. 5

Variants for using fitball in the final part physical education classes. The figure shows the authors' own research results.
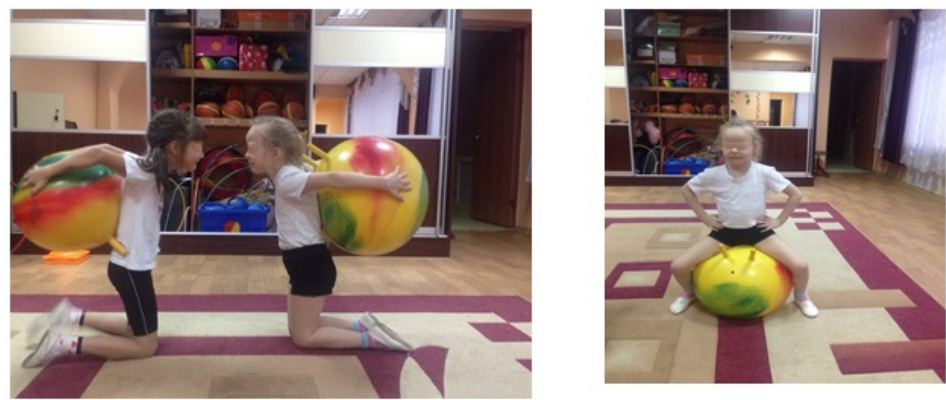

1. Exercises aimed at the formation proper posture

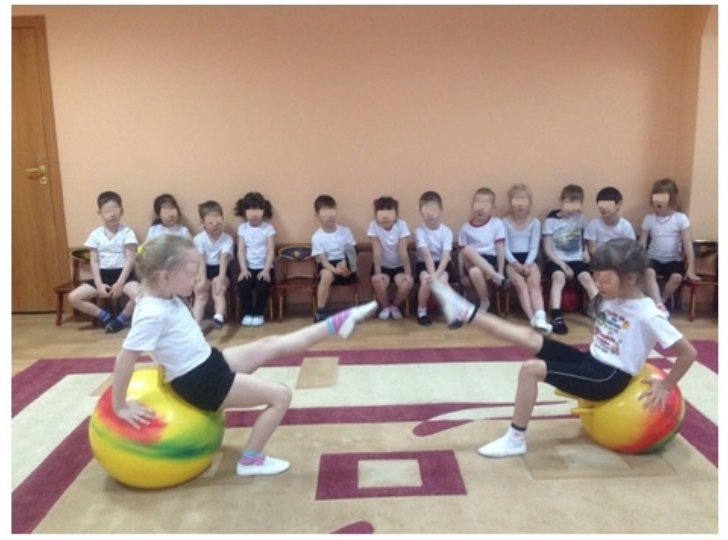

2. Flat feetprevention and Correction Exercises. 
TABLE 2

Comparative characteristics of the level of development of physical abilities of girls 5-6 years of experimental groups before the experiment (September 2016). The table shows the authors' own research results.

\begin{tabular}{|c|c|c|c|c|c|}
\hline \multicolumn{2}{|c|}{ Control exercises } & $\begin{array}{c}\mathrm{EG}(\mathrm{n}=10) \\
(\mathrm{X} \pm \mathrm{m})\end{array}$ & $\begin{array}{c}C G(n=10) \\
(\mathrm{X} \pm \mathrm{m})\end{array}$ & $\mathrm{t}$ & $\mathrm{p}$ \\
\hline \multicolumn{6}{|c|}{ Speed abilities } \\
\hline "Running on $30 \mathrm{n}$ & & $9,5 \pm 0,3$ & $9,6 \pm 0,3$ & 0,1 & $>0,05$ \\
\hline \multicolumn{6}{|c|}{ Coordination abilities } \\
\hline "Shuttle 3x10" (S) & & $12,5 \pm 0,2$ & $12,7 \pm 0,1$ & 0,2 & $>0,05$ \\
\hline \multicolumn{6}{|c|}{ Speed-power abilities } \\
\hline \multicolumn{2}{|l|}{$\begin{array}{l}\text { "Long jump from } \\
\text { Standstill "(sm) }\end{array}$} & $68,3 \pm 2,5$ & $67,5 \pm 4,8$ & 0,8 & $>0,05$ \\
\hline \multicolumn{2}{|c|}{$\begin{array}{l}\text { "Raising the torso to } \\
\text { sitting position" } \\
\text { (number of times in } 30 \\
\text { s) }\end{array}$} & $7,8 \pm 0,8$ & $7,3 \pm 0,9$ & 0,5 & $>0,05$ \\
\hline \multicolumn{6}{|c|}{ Power } \\
\hline \multirow{2}{*}{\begin{tabular}{|l} 
"Dynamometry" \\
$(\mathrm{kg})$
\end{tabular}} & $\mathrm{RH}$ & $6,4 \pm 0,5$ & $6,3 \pm 0,4$ & 0,1 & $>0,05$ \\
\hline & $\mathrm{LH}$ & $5,8 \pm 0,6$ & $5,6 \pm 0,8$ & 0,2 & $>0,05$ \\
\hline \multicolumn{6}{|c|}{ Flexibility } \\
\hline \multicolumn{2}{|l|}{ "Bend forward" (sm) } & $1,6 \pm 1,2$ & $1,7 \pm 1,1$ & 0,1 & $>0,05$ \\
\hline
\end{tabular}

$\mathrm{RH}$ - right hand; $\mathrm{LH}$ - left hand

TABLE 3

Comparative characteristics of indicators of the level of development of physical abilities of boys of 5-6 years of experimental groups before the experiment (September 2016). The table shows the authors' own research results.

\begin{tabular}{|c|c|c|c|c|c|}
\hline \multicolumn{2}{|c|}{ Control exercises } & $\begin{array}{c}\mathrm{EG}(\mathrm{n}=10) \\
(\mathrm{X} \pm \mathrm{m})\end{array}$ & $\begin{array}{c}C G(\mathrm{n}=10) \\
(\mathrm{X} \pm \mathrm{m})\end{array}$ & $\mathrm{t}$ & $\mathrm{p}$ \\
\hline \multicolumn{6}{|c|}{ Speed abilities } \\
\hline "Running on $30 \mathrm{~m}$ & & $9,4 \pm 0,3$ & $9,5 \pm 0,3$ & 0,1 & $>0,05$ \\
\hline \multicolumn{6}{|c|}{ Coordination abilities } \\
\hline "Shuttle 3x10" (S) & & $12,5 \pm 0,2$ & $12,4 \pm 0,1$ & 0,1 & $>0,05$ \\
\hline \multicolumn{6}{|c|}{ Speed-power abilities } \\
\hline \multicolumn{2}{|l|}{$\begin{array}{l}\text { "Long jump from } \\
\text { standstill "(sm) }\end{array}$} & $68,7 \pm 3,1$ & $68,5 \pm 3,3$ & 0,2 & $>0,05$ \\
\hline \multicolumn{2}{|c|}{$\begin{array}{l}\text { "Raising the torso to } \\
\text { sitting position" } \\
\text { (number of times in } 30 \\
\text { S) }\end{array}$} & $7,9 \pm 0,8$ & $7,6 \pm 0,8$ & 0,3 & $>0,05$ \\
\hline \multicolumn{6}{|c|}{ Power } \\
\hline \multirow{2}{*}{$\begin{array}{l}\text { "Dynamometry" } \\
(\mathrm{kg})\end{array}$} & $\mathrm{RH}$ & $6,7 \pm 0,3$ & $6,5 \pm 0,2$ & 0,2 & $>0,05$ \\
\hline & $\mathrm{LH}$ & $5,8 \pm 0,4$ & $5,7 \pm 0,3$ & 0,1 & $>0,05$ \\
\hline \multicolumn{6}{|c|}{ Flexibility } \\
\hline "Bend forward" (Sr & & $0,0 \pm 2,0$ & $0,1 \pm 2,0$ & 1,1 & 0,05 \\
\hline
\end{tabular}

RH - right hand; LH - left hand

After the first year of experimental work, significant differences were noted in the physical abilities of children's engaged in experimental methods and their peers from the control group of both boys and girls (table 4; 5). At the same time, differences in the results demonstrated by boys and girls were noted. The girls of the experimental group had higher gains in running $30 \mathrm{~m}(\mathrm{~s})$, long jump from the standstill $(\mathrm{sm})$, abdominal 
muscle strength (getting up from a sitting position), right arm strength, leaning forward ( $\mathrm{sm}$ ), than their peers from the control group (table 6; figure 6). In turn, the boys of the experimental group were significantly ahead of the boys of the control group in terms of an increase in performance in running $30 \mathrm{~m}(\mathrm{~s})$, shuttle running $3 \times 10(\mathrm{~s})$, long jump from the standstill (sm), lifting the body from a sitting position (number times), dynamometry of the right hand $(\mathrm{kg})$, left hand $(\mathrm{kg})$, leaning forward $(\mathrm{sm})$ (table 6; Figure 7 ).

TABLE 4

Comparative characteristics of indicators of the level of development of physical abilities of girls of 5-6 years of experimental groups after the first year of the experiment (May 2017). The table shows the authors' own research results.

\begin{tabular}{|c|c|c|c|c|c|}
\hline \multicolumn{2}{|c|}{ Control exercises } & $\begin{array}{c}\mathrm{EG}(\mathrm{n}=10) \\
(\mathrm{X} \pm \mathrm{m})\end{array}$ & $\begin{array}{c}C G(n=10) \\
(X \pm m)\end{array}$ & $\mathrm{t}$ & $\mathrm{p}$ \\
\hline \multicolumn{6}{|c|}{ Speed abilities } \\
\hline "Running on $30 \mathrm{I}$ & (S) & $7,8 \pm 0,4$ & $8,8 \pm 0,3$ & 2,0 & $<0,05$ \\
\hline \multicolumn{6}{|c|}{ Coordination abilities } \\
\hline "Shuttle 3x10" (S) & & $10,0 \pm 0,2$ & $11,6 \pm 0,2$ & 2,0 & $<0,05$ \\
\hline \multicolumn{6}{|c|}{ Speed-power abilities } \\
\hline $\begin{array}{l}\text { "Long jump from } \\
\text { standstill "(sm) }\end{array}$ & & $96,0 \pm 1,8$ & $79,5 \pm 4,6$ & 2,1 & $<0,05$ \\
\hline $\begin{array}{l}\text { "Raising the torso } \\
\text { sitting position" } \\
\text { (number of times } \\
30 \text { s) }\end{array}$ & & $11,6 \pm 1,0$ & $8,4 \pm 0,1$ & 3,2 & $<0,05$ \\
\hline \multicolumn{6}{|c|}{ Power } \\
\hline \multirow{2}{*}{$\begin{array}{l}\text { "Dynamometry" } \\
(\mathrm{kg})\end{array}$} & $\mathrm{RH}$ & $8,0 \pm 0,4$ & $6,7 \pm 0,5$ & 2,5 & $<0,05$ \\
\hline & $\mathrm{LH}$ & $7,0 \pm 0,4$ & $5,8 \pm 0,6$ & 2,0 & $<0,05$ \\
\hline \multicolumn{6}{|c|}{ Flexibility } \\
\hline "Bend forward" (s & & $4,1 \pm 1,6$ & $2,2 \pm 0,2$ & 2,1 & $<0,05$ \\
\hline
\end{tabular}

$\mathrm{RH}$ - right hand; $\mathrm{LH}$ - left hand

TABLE 5

Comparative characteristics of indicators of the level of development of physical abilities of boys of 5-6 years of experimental groups after the first year of the experiment (May 2017). The table shows the authors' own research results.

\begin{tabular}{|c|c|c|c|c|c|}
\hline \multicolumn{2}{|c|}{ Control exercises } & $\begin{array}{c}\mathrm{EG}(\mathrm{n}=10) \\
(\mathrm{X} \pm \mathrm{m})\end{array}$ & $\begin{array}{c}C G(n=10) \\
(\mathrm{X} \pm \mathrm{m})\end{array}$ & $\mathrm{t}$ & $\mathrm{p}$ \\
\hline \multicolumn{6}{|c|}{ Speed abilities } \\
\hline "Running on $30 \mathrm{n}$ & (S) & $7,7 \pm 0,2$ & $9,3 \pm 0,3$ & 2,6 & $<0,05$ \\
\hline \multicolumn{6}{|c|}{ Coordination abilities } \\
\hline "Shuttle 3x10" (S) & & $9,9 \pm 0,1$ & $11,9 \pm 0,2$ & 2,2 & $<0,05$ \\
\hline \multicolumn{6}{|c|}{ Speed-power abilities } \\
\hline $\begin{array}{l}\text { "Long jump from } \\
\text { standstill "(sm) }\end{array}$ & & $97,4 \pm 1,7$ & $79,8 \pm 4,1$ & 2,0 & $<0,05$ \\
\hline $\begin{array}{l}\text { "Raising the torso } \\
\text { sitting position" } \\
\text { (number of times } \\
\text { 30 s) }\end{array}$ & & $12,8 \pm 0,1$ & $8,4 \pm 0,3$ & 2,1 & $<0,05$ \\
\hline \multicolumn{6}{|c|}{ Power } \\
\hline \multirow{2}{*}{$\begin{array}{l}\text { "Dynamometry" } \\
\text { (kg) }\end{array}$} & $\mathrm{RH}$ & $8,4 \pm 0,6$ & $7,1 \pm 0,3$ & 2,0 & $<0,05$ \\
\hline & $\mathrm{LH}$ & $8,5 \pm 0,4$ & $6,0 \pm 0,2$ & 2,5 & $<0,05$ \\
\hline \multicolumn{6}{|c|}{ Flexibility } \\
\hline "Bend forward" (s & & $3,3 \pm 0,9$ & $0,2 \pm 0,1$ & 3,1 & $<0,05$ \\
\hline
\end{tabular}


TABLE 6

The increase in physical abilities of children 56 years of experimental groups after the first and second years of the experiment in \% The table shows the authors' own research results

\begin{tabular}{|c|c|c|c|c|c|c|c|c|}
\hline & \multicolumn{4}{|c|}{$\begin{array}{l}\text { After the first year of the } \\
\text { experiment (May 2017) }\end{array}$} & \multicolumn{4}{|c|}{$\begin{array}{l}\text { After the second year of the } \\
\text { experiment (May 2017) }\end{array}$} \\
\hline $\begin{array}{l}\text { Control } \\
\text { exercises }\end{array}$ & $\begin{array}{c}E G \\
(\text { boys }) \\
(n=10)\end{array}$ & $\begin{array}{c}C G \\
(\mathrm{boys}) \\
(n=10)\end{array}$ & $\begin{array}{c}\mathrm{EG} \\
(\mathrm{girls}) \\
(\mathrm{n}=10)\end{array}$ & $\begin{array}{c}C G \\
\text { (girls) } \\
(n=10)\end{array}$ & $\begin{array}{c}\mathrm{EG} \\
(\mathrm{boys}) \\
(\mathrm{n}=10)\end{array}$ & $\begin{array}{c}C G \\
(\text { boys }) \\
(n=10)\end{array}$ & $\begin{array}{c}\text { EG } \\
\text { (girls) } \\
(n=10)\end{array}$ & $\begin{array}{c}C G \\
\text { (girls) } \\
(n=10)\end{array}$ \\
\hline $\begin{array}{l}\text { "Running } \\
\text { on } 30 \\
\mathrm{~m}^{\prime \prime}(\mathrm{s})\end{array}$ & 19,5 & 9,0 & 19,3 & 8,5 & 31,6 & 16,8 & 29,8 & 16,1 \\
\hline $\begin{array}{l}\text { "Shuttle } \\
3 \times 10 "(S)\end{array}$ & 22,9 & 13,9 & 11,3 & 8,0 & 28,0 & 22,1 & 25,0 & 16,8 \\
\hline $\begin{array}{l}\text { "Long } \\
\text { jump } \\
\text { from } \\
\text { standstill } \\
\text { "(sm) }\end{array}$ & 34,4 & 18,1 & 33,6 & 16,2 & 52,3 & 42,5 & 49,1 & 39,5 \\
\hline $\begin{array}{l}\text { "Raising } \\
\text { the torso } \\
\text { to sitting } \\
\text { position" } \\
\text { (number } \\
\text { of times } \\
\text { in } 30 \mathrm{~s} \text { ) }\end{array}$ & 46,8 & 14,7 & 39,6 & 13,7 & 55,1 & 26,5 & 53,0 & 24,5 \\
\hline $\begin{array}{l}\text { "Dynamo } \\
\text {-metry" } \\
\text { (kg): } \\
\text { right left }\end{array}$ & $\begin{array}{l}22,1 \\
37,1\end{array}$ & $\begin{array}{l}8,6 \\
5,0\end{array}$ & $\begin{array}{l}21,8 \\
18,4\end{array}$ & $\begin{array}{l}6,0 \\
3,3\end{array}$ & $\begin{array}{l}45,4 \\
55,1\end{array}$ & $\begin{array}{l}34,0 \\
35,8\end{array}$ & $\begin{array}{l}44,2 \\
50,5\end{array}$ & $\begin{array}{l}32,8 \\
29,8\end{array}$ \\
\hline $\begin{array}{l}\text { "Bend } \\
\text { forward" } \\
\text { (sm) }\end{array}$ & 20,0 & 9,0 & 44,6 & 24,3 & 39,0 & 26,7 & 46,0 & 32,0 \\
\hline
\end{tabular}

FIG. 6

Growth in the indicators of physical abilities of girls experimental groups after the first year of the experiment, in\% (May 2017). The figure shows the authors' own research results.

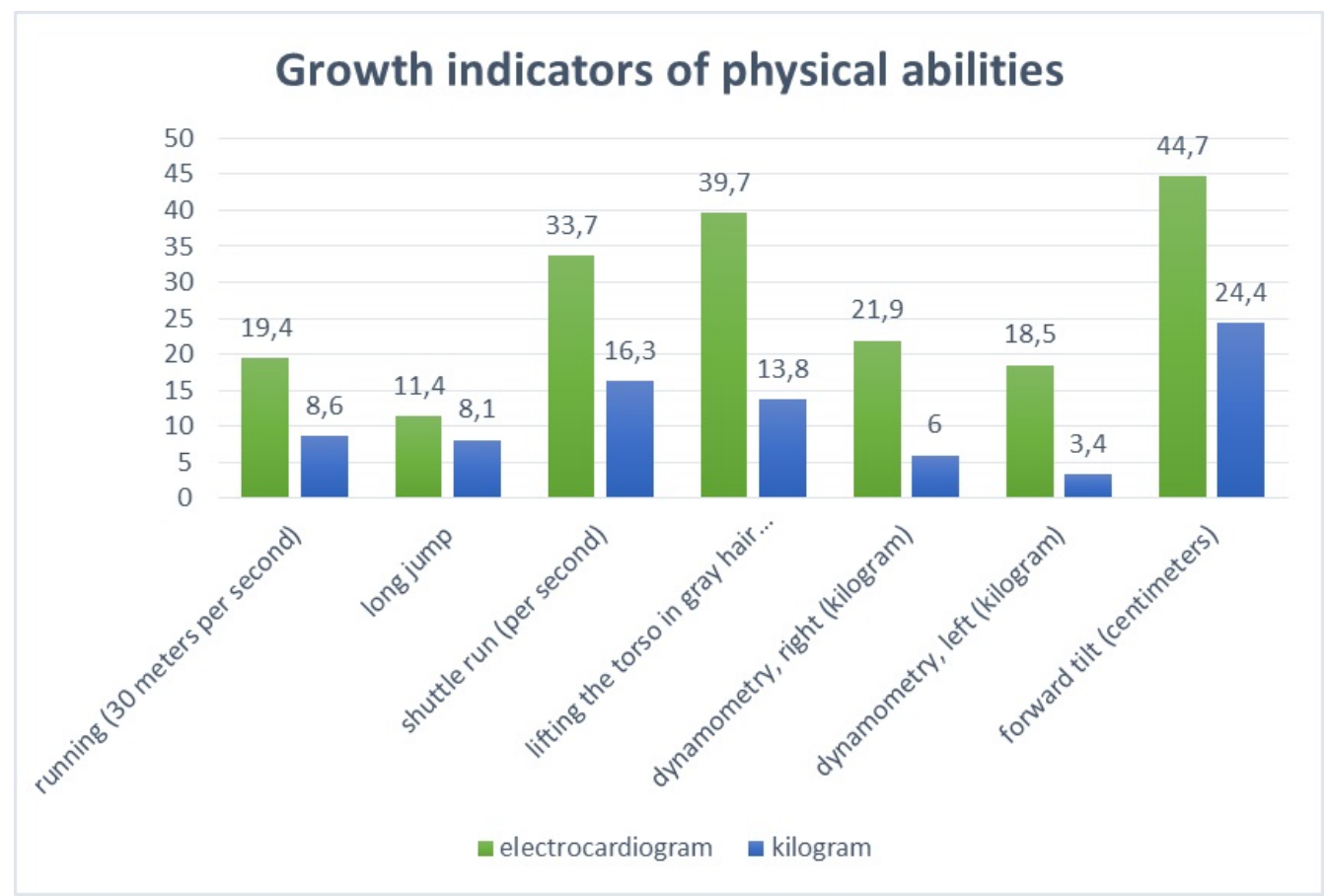


FIG. 7

Growth indicators of physical abilities of boys experimental groups after the first year of the experiment, in\% (May 2017). The figure shows the authors' own research results.

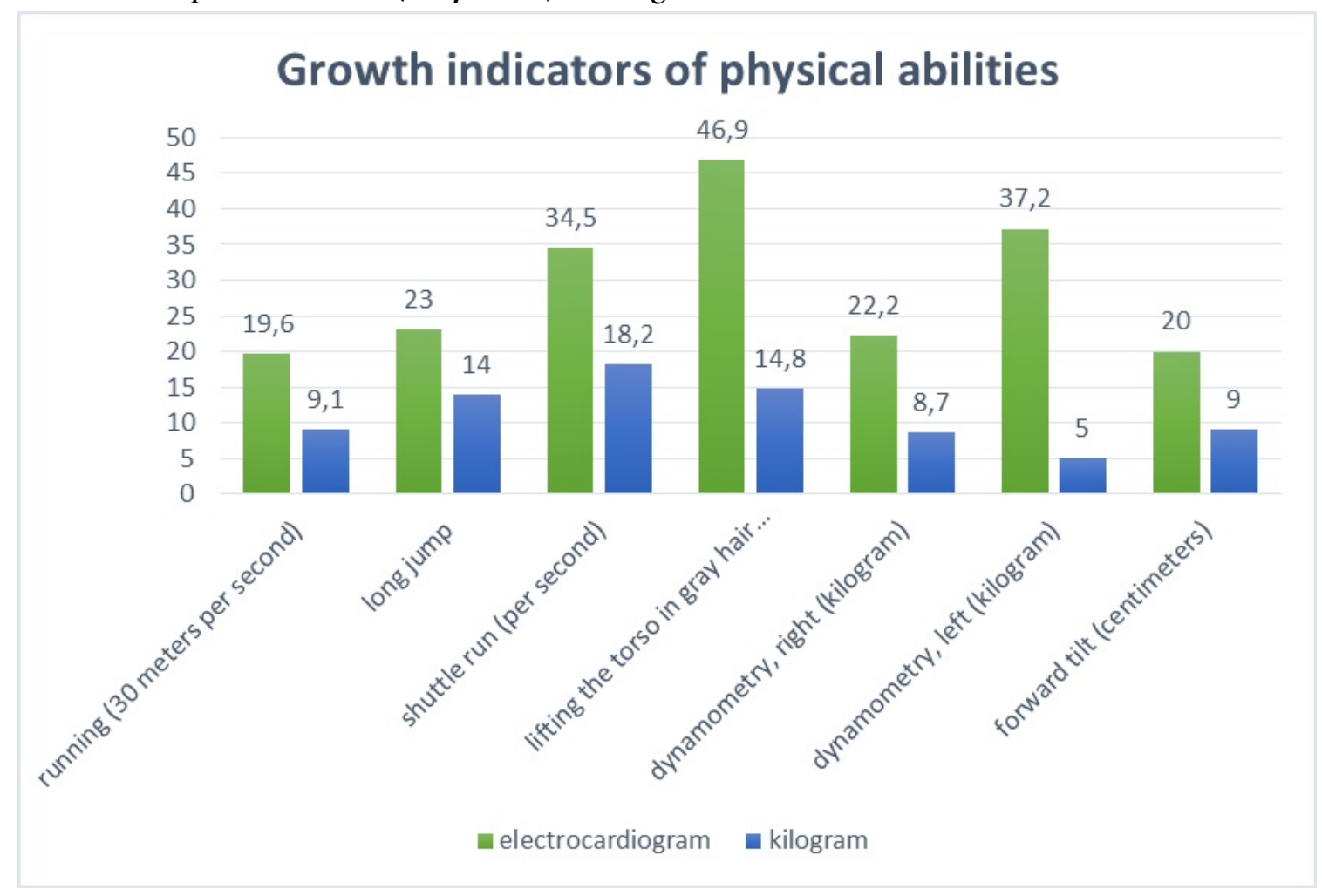

By the end of the second year of the experimental work, significant differences in all the studied indicators of the physical abilities of children in the control and experimental groups became more pronounced (tables $7,8)$. The increase in physical abilities after the second year of the study turned out to be the most significant in the experimental group, in terms of speed, coordination, speed-strength, strength abilities and flexibility in both boys and girls (table 6; Fig. 8; 9). 
TABLE 7

Comparative characteristic of girls aged 6-7 physical abilities developmental level indication at experimental groups at the end of the second year of the experiment (May 2018). The table shows the authors' own research results.

\begin{tabular}{|c|c|c|c|c|c|}
\hline \multicolumn{2}{|c|}{ Control exercises } & $\begin{array}{c}\mathrm{EG}(\mathrm{n}=10) \\
(\mathrm{X} \pm \mathrm{m})\end{array}$ & $\begin{array}{c}C G(n=10) \\
(X \pm m)\end{array}$ & $\mathrm{t}$ & $\mathrm{p}$ \\
\hline \multicolumn{6}{|c|}{ Speed abilities } \\
\hline "Running on $30 \mathrm{~m}$ & (S) & $7,0 \pm 0,3$ & $8,0 \pm 0,6$ & 2,5 & $<0,05$ \\
\hline \multicolumn{6}{|c|}{ Coordination abilities } \\
\hline "Shuttle $3 \times 10 "$ (S) & & $9,7 \pm 0,1$ & $10,7 \pm 0,3$ & 2,3 & $<0,05$ \\
\hline \multicolumn{6}{|c|}{ Speed-power abilities } \\
\hline $\begin{array}{l}\text { "Long jump from } \\
\text { standstill "(sm) }\end{array}$ & & $113,0 \pm 3,5$ & $101,0 \pm 4,0$ & 2,4 & $<0,05$ \\
\hline $\begin{array}{l}\text { "Raising the torso } \\
\text { sitting position" } \\
\text { (number of times } \\
30 \mathrm{~s} \text { ) }\end{array}$ & & $13,5 \pm 1,3$ & $10,4 \pm 0,1$ & 2,5 & $<0,05$ \\
\hline \multicolumn{6}{|c|}{ Power } \\
\hline \multirow{2}{*}{$\begin{array}{l}\text { "Dynamometry" } \\
\text { (kg) }\end{array}$} & $\mathrm{RH}$ & $10,1 \pm 0,2$ & $9,4 \pm 0,9$ & 2,2 & $<0,05$ \\
\hline & $\mathrm{LH}$ & $9,8 \pm 0,3$ & $9,1 \pm 0,1$ & 2,3 & $<0,05$ \\
\hline \multicolumn{6}{|c|}{ Flexibility } \\
\hline "Bend forward" (SI & & $7,4 \pm 0,7$ & $4,5 \pm 1,6$ & 2,1 & $<0,05$ \\
\hline
\end{tabular}

$\mathrm{RH}$ - right hand; LH - left hand

TABLE 8

Comparative characteristic of boys aged 67 physical abilities developmental level indication at experimental groups at the end of the second year of the experiment May 2018 The table shows the authors' own research results

\begin{tabular}{|c|c|c|c|c|c|}
\hline \multicolumn{2}{|c|}{ Control exercises } & $\begin{array}{c}E G(n=10) \\
(\mathrm{X} \pm m)\end{array}$ & $\begin{array}{c}C G(n=10) \\
(\mathrm{X} \pm \mathrm{m})\end{array}$ & $\mathrm{t}$ & $\mathrm{p}$ \\
\hline \multicolumn{6}{|c|}{ Speed abilities } \\
\hline "Running on $30 \mathrm{~m}$ & (S) & $6,8 \pm 0,4$ & $8,1 \pm 0,4$ & 2,6 & $<0,05$ \\
\hline \multicolumn{6}{|c|}{ Coordination abilities } \\
\hline "Shuttle $3 \times 10 "$ (s) & & $9,4 \pm 0,2$ & $10,0 \pm 0,3$ & 2,1 & $<0,05$ \\
\hline \multicolumn{6}{|c|}{ Speed-power abilities } \\
\hline $\begin{array}{l}\text { "Long jump from } \\
\text { standstill "(sm) }\end{array}$ & & $117,5 \pm 5,8$ & $105,6 \pm 5,1$ & 2,5 & $<0,05$ \\
\hline $\begin{array}{l}\text { "Raising the torso } \\
\text { sitting position" } \\
\text { (number of times } \\
30 \text { s) }\end{array}$ & & $14,1 \pm 1,8$ & $9,1 \pm 1,0$ & 2,3 & $<0,05$ \\
\hline \multicolumn{6}{|c|}{ Power } \\
\hline \multirow{2}{*}{$\begin{array}{l}\text { "Dynamometry" } \\
(\mathrm{kg})\end{array}$} & $\mathrm{RH}$ & $10,8 \pm 0,8$ & $7,5 \pm 1,0$ & 2,3 & $<0,05$ \\
\hline & \begin{tabular}{|l}
$\mathrm{LH}$ \\
\end{tabular} & $10,3 \pm 0,6$ & $6,7 \pm 0,9$ & 2,6 & $<0,05$ \\
\hline \multicolumn{6}{|c|}{ Flexibility } \\
\hline "Bend forward" (s & & $6,1 \pm 1,1$ & $4,5 \pm 1,7$ & 2,2 & $<0,05$ \\
\hline
\end{tabular}

$\mathrm{RH}$ - right hand; LH - left hand 
FIG. 8

Growth indicators of physical abilities of girls experimental groups after the second year of the experiment, in\% (May 2018). The figure shows the authors' own research results.

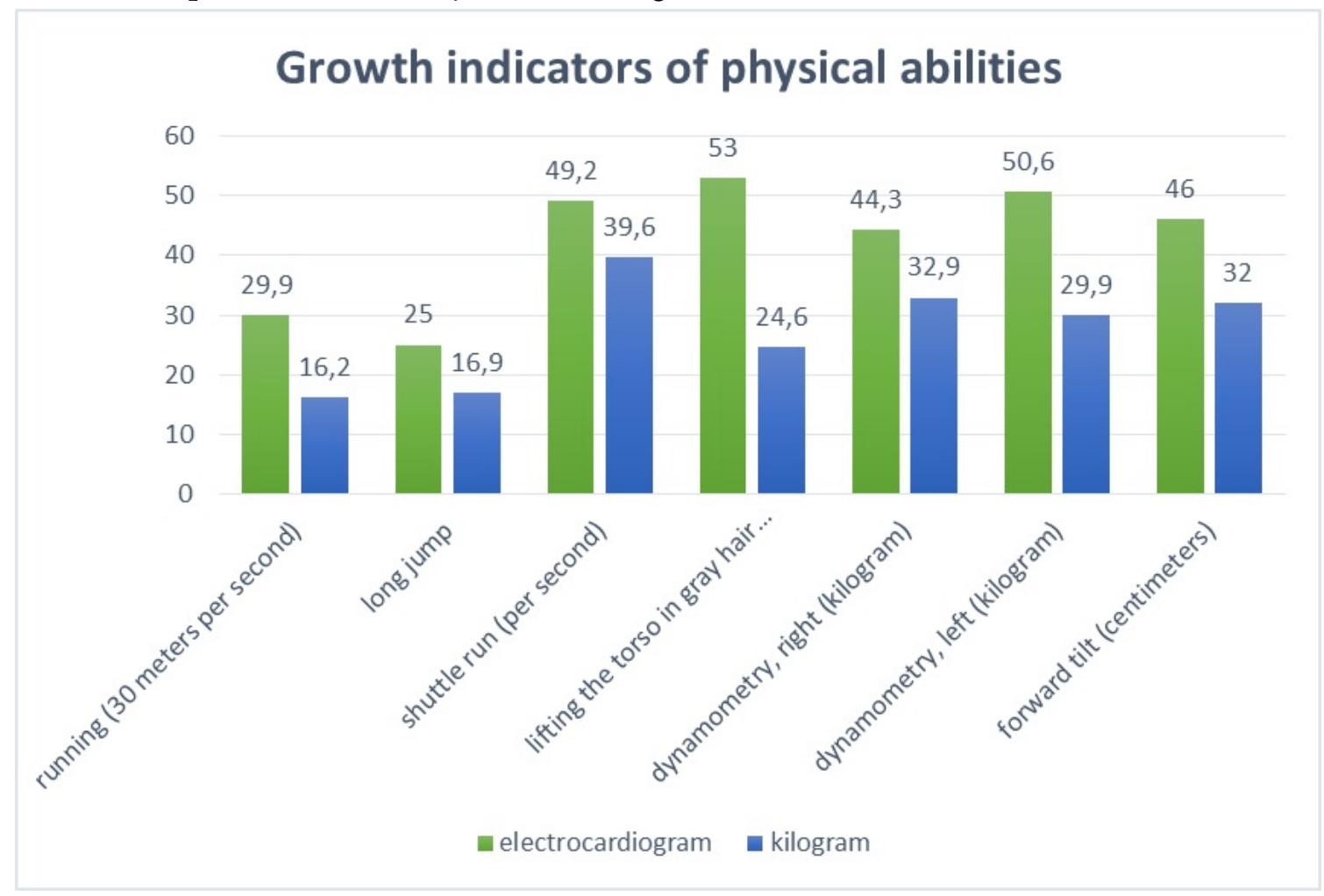

FIG. 9

Growth indicators of physical abilities of boys experimental groups after the second year of the experiment, in\% (May 2018). The figure shows the authors' own research results.

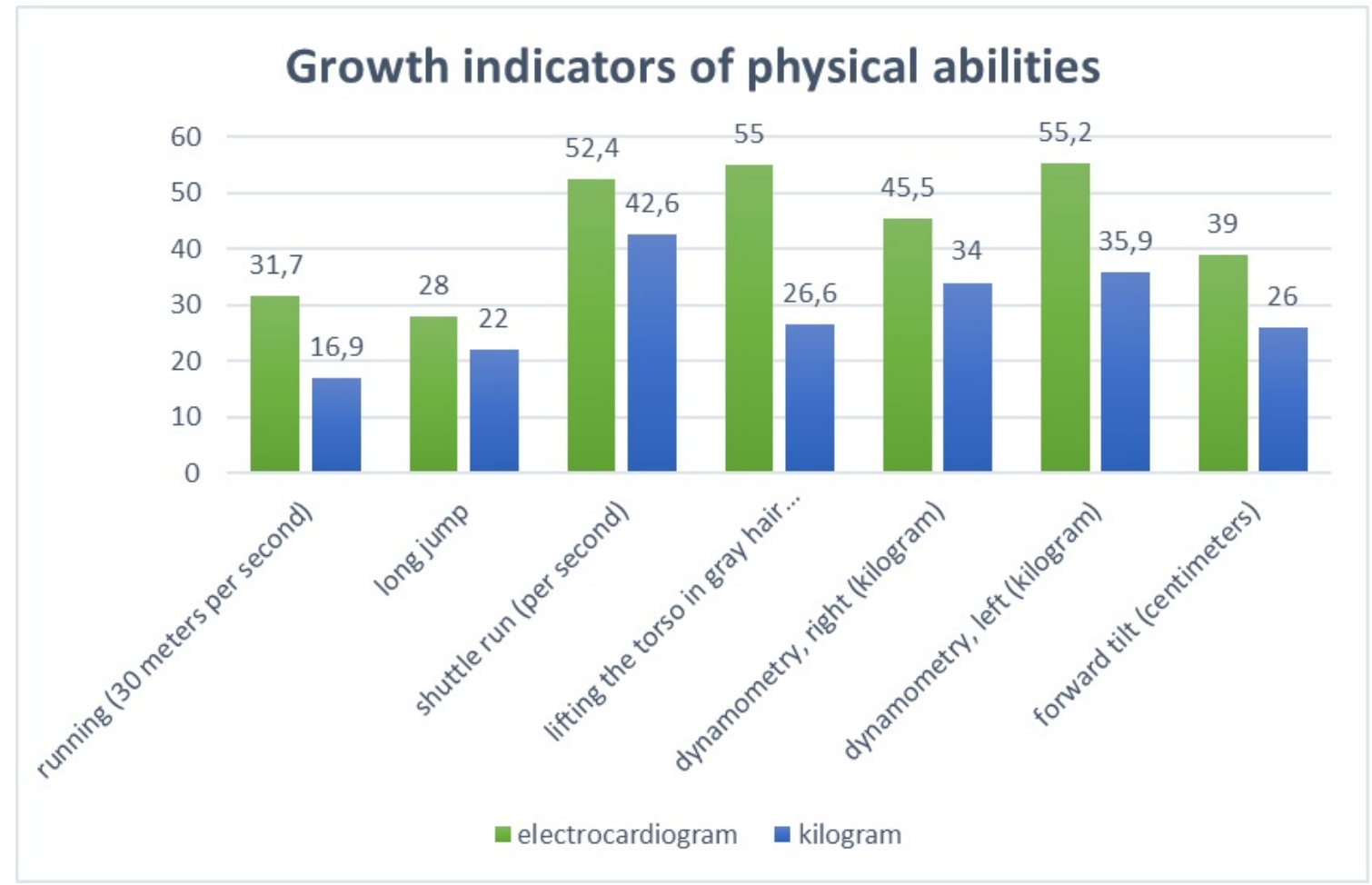


The pulsometry data showed that when conducting classes according to the experimental methodology, the load at all stages of the lesson corresponded to the children's abilities and the recommendations of the research institutes of the Russian Academy of Education. An analysis of the dynamics of heart rate $(\mathrm{HR})$ in the classes in the experimental and control groups showed (Figure 10) that physical activity in the experimental group has a more pronounced training effect on the children's body compared to the load in the classes in the control group. The motor density (30 lessons) in PE lessons in the experimental group ranged from $60-65$ to $75-86 \%$ depending on the tasks and type of activity, while in the control group (30 lessons) it was lower and amounted to 50-65\%. Thus, the data of pulsometry and timing to a certain extent confirm the effectiveness of physical culture classes using fitball-aerobics.

FIGURE 10

Dynamics of heart rate in the process physical education classes in the experimental and control groups. The figure shows the authors' own research results.

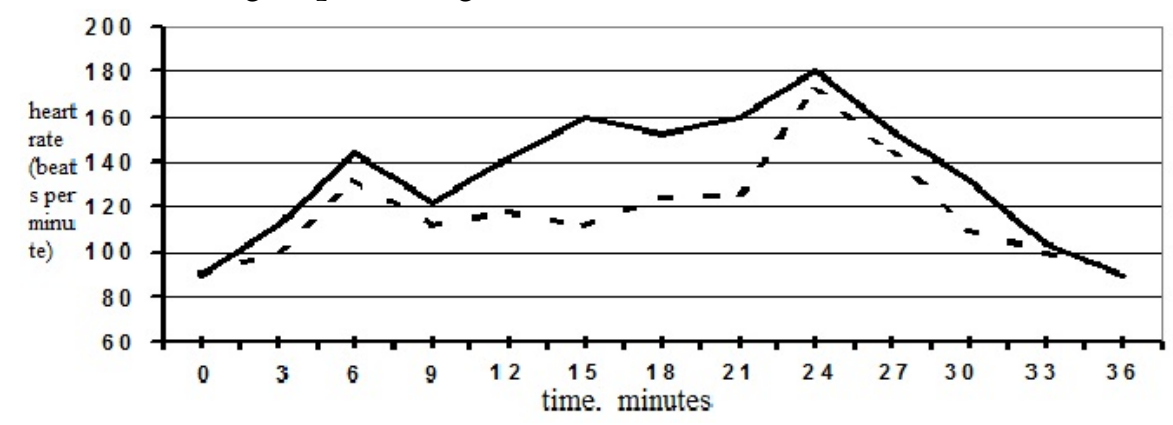

Legend :

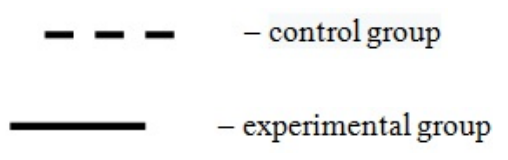

\section{Discussion And Conclusions}

The results of the study confirmed the hypothesis put forward by us.

Fitball-aerobics is one of the innovative means of physical education for preschool children, which is confirmed by foreign scientific research (Pappas et al., 2013)

Fitball-aerobics has four historical stages of development: I - "Use of fitballs for medicinal purposes", II - "Fit-ball gymnastics development", III - "Appearance fitball- aerobics", IV - "Further development of fitball-aerobics"; it has specific features, a wide variety of means and has the ability to use them with the aim of treating the musculoskeletal system (Singh-Grewal et al., 2006), the disease of vegetative-vascular dystonia of mixed type (Olchovik, 2015), respiratory, cardiovascular and nervous systems of the body in-volved.

Fitball aerobics helps to solve the following problems:

- $\quad$ motor qualities development (speed, endurance, flexibility, strength, dexterity);

- training in basic motor actions;

- development and improvement of coordination of movements and balance;

- strengthening the muscle corset, creating the skill of correct posture and the development of the optimal motor stereotype;

- improving the functioning of the cardiovascular and respiratory systems; 
- normalization of the nervous system work, stimulation of neuropsychic development;

- improving blood supply to the spine, joints and internal organs, eliminating venous stasis;

- improving the communicative and emotional-volitional sphere;

- stimulation of the analyzer systems development, proprioceptive sensitivity;

- development of fine motor skills and speech; body adaptation to physical activity.

As a result of theoretical studies, it was determined that the complexity of the effects of fitball-aerobics exercises occurs due to the following factors:

- properties of fitball (large size, round shape, bright colors, elasticity, vanilla-candy smell);

- multifunctionality of its use (ball as: support, weight, object, simulator, landmark, obstacle, massager);

- $\quad$ purposefully selected means;

- musical accompaniment.

The performed analysis of scientific and methodological literature showed that the main means of fitballaerobics used in the process preschool children's physical education are:

- gymnastic exercises (drill exercises, varieties of walking, running, jumping, general developmental exercises);

- basic aerobics exercises (connected in blocks and combinations);

- dance exercises (elements of rhythm, choreography and modern dances);

- preventive corrective exercises (exercises aimed at the prevention of vegetative-vascular dystonia of mixed type (Olchovik, 2015), of flat feet, posture disorders and other diseases, Pilot study of fitness training and exercise testing in polyarticular childhood arthritis (Singh-Grewal et al., 2006);

- active and musical games and relay races;

- exercises from other types of physical culture (elements of athletic gymnastics, applied gymnastics, basketball, yoga, etc.).

In the course of the study, the concept of "physical abilities" was clarified by which we mean individual qualities that determine the level of a person's motor capabilities that are associated with the success of any activity. The basis of a person's motor abilities are physical qualities, and the manifestation form - is motor skills. Motive abilities include power, speed, speed-power, motor-coordination abilities, general and specific endurance (Tsaklis et al., 2015).

A methodology has been developed and tested for the complex effect of fitball-aerobics exercises on the physical abilities older preschool children development, including appropriate methods (playing, competitive), means (gymnastic exercises (drill exercises, varieties of walking, running, jumping, general developmental exercises; basic aerobics exercises (connected in blocks and combinations); abdominal muscle activity while performing trunk-flexion exercises using the fitbal (Hildenbrand \& Noble, 2004); dance exercises (elements of rhythm, choreography and modern dances); preventive corrective exercises (exercises aimed at the prevention of flat feet, posture disorders and other diseases); active and music games and relay races; exercises from other types of physical education (elements of athletic gymnastics, applied gymnastics, basketball, yoga, etc.).

Physical education based on the use of fitball-aerobics elements have a positive impact on the development of physical abilities of preschool children aged 5-7, motivates to engage in physical culture and sports (Stepanov, 2019). At the end of the pedagogical experiment, the children of the experimental group showed significantly higher results than peers from the control group $(\mathrm{p}<0.05)$ in the tests: "30 m run", "Shuttle run $3 \times 10 \mathrm{~m}$ ", "Long jump from standstill", "Bending the torso to sitting position", "Dynamometria" (kg), Bend forward (sm). 
Conflicts of interest: The author declared no potential conflicts of interest with respect to the research, authorship, and/or publication of this article.

\section{REFERENCES}

Bedran, R. (2016). Technique of health culture education of preschool children in different age groups. Science and Education, 10, 194-199.

Borisova, M. M. (2012). Modernization of the physical education of preschool children taking into account modern fitness technologies. Actual problems and trends of modern preschool education: collection. scientific Art. Minsk: BSPU, 53-55.

Denisenko, A. N. (2014). Influence of fitball gymnastics on the physical development of preschool children. Problems andprospectsfor the development of education: materials Vint. scientific conf. (Perm, March 2014). Perm : Mercury, pp. 64-66.

Grjibovski, A.M. (2003). Social variations in fetal growth in Northwest Russia: an analysis of medical records. Annals of Epidemiology, 9, 599-605.

Grizik, T. I., Doronova, T. N., Solovyova, E. V. \& Jacobson, S. G. (2010). Raduga (Rainbow): a program for the upbringing, education and development of children aged from 2 to 7 years old in kindergarten. Moscow: Education

Hildenbrand, K. \& Noble, L (2004). Abdominal muscle activity while performing trunk-flexion exercises using the ab roller, ABslide, fitBall, and conventionally performed trunk curlsə. Journal of athletic training, 1(39), 37-43.

Kolesnikova, C. B. (2005). Children's aerobics: a technique, basic complexes. Rostov-on-Don: Phoenix

Kondakov, V. L., Voloshina, L.N., Kopeikina, E. N., Kadutskaya, L. (2020). Daily assessment of physical activity in 6-11-year-old children. Journal of Physical Education and Sport, 4, Art. 227, 1673 - 1680, DOI: https://10.7 752/jpes.2020.04227

Kuchma, V. R. (2006). Modern technologies for the rehabilitation of children and adolescents in educational institutions: a manual for doctors. Tyumen: Academy, $60 \mathrm{p}$.

Lobanov, Y. F., Strozenko, L. A., Mikheeva, N. M., Fugol, D. S., \& Latyshev, D. Y. (2019). Quality of life for children examined at the health center. Health, Physical Culture and Sports, 4(15), 309-314. Retrieved from: http://jou rnal.asu.ru/zosh/article/view/7112

Mishchenko, N. Yu. (2019). The use of aerobics in the physical education of girls aged 12-14, using modern information technologies. Physical Culture and Sports: Science, Education, Technologies: Materials of All-Russian. scientific and practical conf. undergraduates (April 12, 2019). Chelyabinsk: UralSUPC, pp. 100-105.

Metalnikov, A. I., Kraynik V.L., Romanova, E. V., Kolokoltsev, M. M., Botagariyev T.A., Kubieva S. S. (2020) Methods for the prevention of scheuermann's disease in children with hereditary disorders of the development of connective tissue. Revista Inclusiones 2020, 7(4), 392 - 409

Metalnikov, A. I., Romanova, E. V., Makunina, O. V., Bykov, E. V., Zhumabayeva, A. Zh., Mamytov, B. K. (2020). Osteopenic syndrome in childhood as part of a traumatologist - orthopedist practice in polyclinic. Revista Inclusiones, Vol. 7, Número Especial, 209 - 220.

Olchovik, A.V. (2015). Physical development and physical preparedness of students of special medical group with the disease of vegetative-vascular dystonia of mixed type. Pedagogics psychology medical-biological problems of physical training and sports, 3(19), 38-45

Ovchinnikova, T. S. \& Potapchuk, A. A. (2009). Active game for preschoolers: a training manual. Saint Petersburg: Speech, $166 \mathrm{p}$.

Pappas, E., Panou, H. \& Souglis, A. (2013).The effect of a pilates exercise programme using fitball on people suffering from chronic low-back pain in terms of pain reduction and function imrovement. Journal of Physical Education and Sport, 4, Art. 95, 606- 611. DOI: https://10.7752/jpes.2013.04095

Pesina, O. N. (2019). Influence of the integrated use of fitness tools on the functional state of the respiratory system and physical fitness of children aged 13-14. Physical Culture. Sport. Tourism, motor recreation, 4(4), $42-48$. 
Protic, M. \& Válková, H. (2018). The relationship between executive functions and physical activity in children with an intellectual disability. Journal of Physical Education and Sport, 2, Art. 125, 844-852.

Saykina, E. G. (2008). Fitball-aerobics for children: “dancing on balls". Saint Petersburg: Publishing House of Russian State Pedagogical University named after A.I. Herzen

Saykina, E. G. \& Kuzmin S.V. (2011). Theoretical and methodological foundations of fitball-aerobics: textbook on fitballaerobics for physical education specialists of preschool and school educational institutions and fitness centers. Saint Petersburg: Publishing House of Russian State Pedagogical University named after A.I. Herzen

Schulz, K. F., Altman, D. G., Moher, D., \& the CONSORT Group. (2010). CONSORT 2010 statement: Updated guidelines for reporting parallel group randomised trials. Annals of Internal Medicine, 152(11), 726-732. DOI: https://10.7326/0003-4819-152-11-201006010-00232

Singh-Grewal, D., Wright, V. \& Bar-Or, O. (2006). Pilot study of fitness training and exercise testing in polyarticular childhood arthritis. Arthritis \& rheumatism-arthritis care \& research, 3(55), 364-372.

Stepanov, A. P. (2019). Motivation of preventive independent health. Health, Physical Culture and Sports, 4(15), 127-133. Retrieved from http://journal.asu.ru/zosh/article/view/7087

Stepanova, M. I. (2006). Health-saving principles of the organization of school and preschool education. Health, education and upbringing of children: history and modernity (1904-1959-2004). Moscow: Dynasty, pp. 184-193.

Symonik, A. V., Chernenko, O. Ye. \& Chernenko, A. Ye. (2018). Application of fitball aerobics means in the system of physical education of female students of non-sporting specialties. Physical education of students, 3(22), 159-166.

Tsaklis, P., Malliaropoulos, N., Mendiguchia, J. (2015). Muscle and intensity based hamstring exercise classification in elite female track and field athletes: implications for exercise selection during rehabilitation. Open access journal of sports medicine, 6, 209-217

Veselovskaya, S. V. (1998). Fitball training: a manual on fitball-aerobics and fit-ball-gymnastics. Moscow: NNEI Center Fitball

WMA Declaration of Helsinki - Ethical Principles for Medical Research Involving Human Subjects (2013). Available from: http://www.ub.edu/recerca/Bioetica/doc/Declaracio_Helsinki_2013.pdf

Zakharova, O. S. (2013). Caterpillar on fitball: a lesson in corrective gymnastics. Children's Health, September 1, 9, 22-23. 